\section{Challenges in Adequate Management of Hazardous Medical Waste to Reduce Impact of the COVID- 19 Epidemic in Romania}

\section{Victor PLATON1, Simona FRONE ${ }^{2}$ Andreea CONSTANTINESCU ${ }^{3 *}$, Sorina JURIST 4}

${ }^{1}$ Institute of National Economy, Bucharest, Romania, victor.platon54@gmail.com

${ }^{2}$ Institute of National Economy, Bucharest, Romania, frone.simona@gmail.com

${ }^{3}$ Institute of National Economy, Bucharest, Romania, andreea constantinescu07@yahoo.com

* Corresponding author.

${ }^{4}$ Institute of National Economy,

Bucharest, Romania, sorinaj2005@yahoo.com
Abstract: The paper analyses some important challenges faced by the sector of hazardous medical waste (HMW) management in Romania, during the COVID-19 pandemic. In the beginning section, there is a brief presentation of the characteristics and evolution of the epidemic in Romania as compared to the EU and other states, showing the resurgence of cases in the summer of 2020 and the fact that the rate of incidence is high. There is a growing concern on the large additional quantities of hazardous medical waste generated in the context of the pandemic, since according to the recommendations of international health organizations, the proper management of the infectious medical waste is critical for the disease control and for avoiding increased environmental pollution. However, since in the next section there are analysed the main current characteristics and issues of the hazardous medical waste management in Romania (the types of medical waste; legal provisions; the amounts generated, the disposal, processing and treatment facilities, the costs incurred) it may be stated that the COVID-19 pandemic only reinforces the challenges for the management of the already growing amounts of hazardous medical waste having occurred in Romania (from a quantity of 8,900 tons in 2012, rising to 13,031 tons in 2018). Several scenarios of the likely increase in the amount of hazardous medical waste in a short time due to COVID-19 are provided, most probable scenarios B (+50\%) and C $(+75 \%)$ requiring investment in the capacity of hazardous medical waste management, with total values of between 14.67 million $€$ and 18.00 mil. $€$. In the concluding remarks, to highlight the development and innovation opportunities in dealing with the challenges, the paper proposes a series of measures, investment and mechanisms for the adequate management of the HMW in Romania.

Keywords: Covid-19, hazardous medical waste, disposal facilities, investments, measures

How to cite: Platon, V., Frone, S., Constantinescu, A., \& Jurist, S. (2020). Challenges in Adequate Management of Hazardous Medical Waste to Reduce Impact of the COVID19 Epidemic in Romania. In M. W. Staniewski, V. Vasile, \& A. Grigorescu (vol. ed.), Lumen Proceedings: Vol. 14. International Conference Innovative Business Management \& Global

Entrepreneurship (IBMAGE 2020) (pp. 212-226). Iasi, Romania: LUMEN Publishing House.

https://doi.org/10.18662/lumproc/ibmage2020/16 


\section{Introduction}

This article is based on more extensive research carried out in spring 2020 (April-May) by the sector of Sustainable Economic Development within the Institute of National Economy. The subject of the paper was that of medical waste generation which, in the situation of the COVID-19 epidemic, must be managed extremely carefully.

Unfortunately, the COVID-19 pandemic is currently the greatest planetary health, socio-economic and ecological challenge. The very large volume of medical waste resulting and its infectious or dangerous character jeopardize efforts to overcome the epidemic.

Disposal of hazardous medical waste at random or mixing with household waste may lead to contamination of soil and groundwater with chemicals, viruses or bacteria in their composition, resulting in endangering the health of the population and further propagation of pathogens. In the face of a very dangerous epidemic such as the one by COVID-19, the infrastructure needed to dispose of this medical waste safely is essential.

The evolution of COVID-19 infections in 2020 has highlighted a number of weaknesses of the Romanian medical system and some challenges regarding the management of hazardous medical waste, which have favoured the spread of infection to medical personnel, other healthy people, people admitted to hospitals with other conditions, etc. As it is important that deficiencies will be eliminated and increasing the level of protection against infection with highly contagious pathogens, the paper examines these issues and suggests the main strategic directions, measures as well as the investments needed to increase safety in the management of hazardous medical waste in Romania.

\section{Problem Statement}

As part of the ongoing pandemic, the COVID-19 epidemic in Romania is triggered by acute respiratory disorder. Due to the novelty of the coronavirus SARS-CoV-2 and the very high contagious character, the coronavirus disease (COVID-19) has caused a global health crisis. Recent official data [9] show that worldwide in 2020, more than 17 million cases of COVID-19 have been registered, including around 700 thousand deceases persons. In Europe, the most affected countries were England, Italy, Spain.

Beyond the clinical and epidemiological features, there is a growing concern on the huge supplementary quantities of hazardous medical waste (HMW) created in the context of the pandemic. According to the recommendations of international health organizations, the proper 
management of the infectious medical waste is critical for the disease control and for avoiding increased environmental pollution. [18]

Recent dedicated research papers show that reasonable elimination of medical waste is complicated and augmented, particularly in health crises like the COVID-19 epidemic [4]. As regards the quantities of health care waste generated in the context of the pandemic, it is obvious that it will be registered a large jump compared with the situation before the pandemic started. Waste resulting from medical activities increases with the rise in the number of infections. Both patients and medical staff are using individual single-use protective equipment - masks, gloves, protecting suits. All these consumables accumulate as infectious health care residuals that have to be managed securely [8].

In Wuhan, after the epidemy broke out, took place a rapid enhancement of the existing infrastructure in order to cope with rapid increase of the outbreak. In a short period of time was built an hospital and numerous mobile equipment to treat the health care waste that was generated (six time more than before the crisis). Could be mentioned that a quantity of 240 tons/day health care waste was generated [2].

On the other hand, although there is concern and awareness at national and international level, there is currently too little concrete information on the quantities of Covid-19 HMW actually generated and how these are managed. Thus, an expert stated that "regarding changes in medical waste management due to COVID-19, there is not available much quantitative and reliable data yet' [1].

Actually, the main challenges identified by [16] in measures to control unusual medical waste generated in the Covid-19 pandemic are due to the following issues: lack of data; lack of geographical identification; lack of knowledge or capacity.

The present research paper aims to address and analyse these issues concerning the management of the HMW in Romania, with the occasion of the Covid-19 healthcare crisis. Although the topic might have been partially or alternatively approached in other studies, this paper also highlights some issues of costs and investments to be considered for the further consolidation, development and innovation of the HMW sector in Romania.

\section{Research Questions/Aims of the research}

The research question or the main aim of the article is: do existing capacities existing in Romania for eliminating of hazardous medical waste can cope with the surplus of quantities due to the Covid-19 pandemic? The 
investment needs and HMW management innovation directions to deal with the main challenges are also questions covered by the research.

The scenarios developed for the expected increase in medical waste took into account the data available under uncertain conditions. The only certainty is a rapid surge in the cases of Covid-19 infested persons (active cases) in the last about three months in Romania that indirectly validates the concern for the correlated growth in the infectious HMW.

This study can help to base the options for measures and guidance of HMW management development policies in Romania to reduce and prevent the negative effects of the COVID-19 epidemic.

\section{Research Methods}

The research methods used in drafting this article, are varied and are mainly based on:

a) The literature review;

b) The conceptual clarification and analysis of the main variables;

c) The analysis of data regarding the evolution of active cases of Covid19, in Romania and other countries;

d) The research of existing databases and reports on medical waste generated in Romania in the last 10 years;

e) The research of existing databases and recent reports on the methods, equipment and capabilities to dispose of and manage medical waste in Romania;

f) Own processing and analysis of the evolution of variables;

g) The creative taking of data and computational models from the literature (HMW (kg/bed/day) in selected countries; specific investment costs of disposing of hazardous medical waste) and applying them in the context of own research to verify or justify hypotheses and scenarios;

h) The development of scenarios of probable evolution (forecast) of the total quantities of HMW generated annually in Romania during the Covid-19 pandemic.

It should also be noted that the acute data gap regarding the medical waste generated and the fact that there are divergent datasets, strategies and reports that use calculation methods that have changed over time, has made the comparability of the data to be interpreted cautiously. 


\section{Findings}

\subsection{Recent development of the Covid-19 epidemic in Romania and the EU}

The COVID-19 epidemic is a major threat to public health in EU states and all over the world.

Unfortunately, Romania is among those EU countries where the number of cases of Covid-19 incidence increased greatly in the summer of 2020 , after the relaxation of measures taken in the state of emergency.

\section{Active Cases}

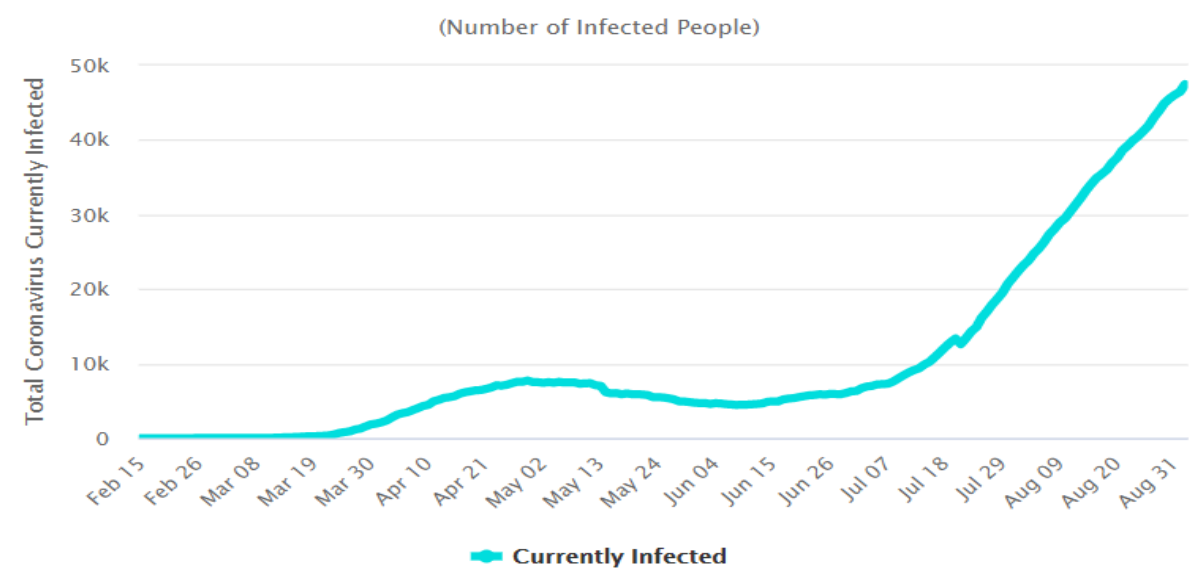

Figure 1: Evolution of the Covid-19 infected people in Romania

Source: www.worldometers.info/coronavirus/country/romania [19]

As of September, $1^{\text {th }} 2020$, the total number of persons that were confirmed Covid-19 in Romania is high: 88593 confirmed cases; 38454 (43.4\%) cured; 46458 (52.4\%) active cases; 3681 (4\%) deceased; 7164 (15\% of active cases) admitted in hospitals, out of which 522 in ICU. More than 230 medical units in Romania had patients who tested positive for the coronavirus. Out of the total number of coronavirus infections in Romania, six percent were represented by the entire personnel working in the medical sector. By August 27 2020, the number of infected employees working in the Romanian healthcare system reached 5,013, from only 2116 in May, 2019, that is a rate of growth of about $137 \%$. [6].

All these data suggest a high and increasing pressure on the Romanian hospitals due to the active Covid-19 pandemic. 
Table 1. Number of beds for 100,000 people in several EU Member States and Romania

\begin{tabular}{lllll}
\hline \multicolumn{1}{c}{ Year/state } & 2015 & 2016 & 2017 & 2018 \\
\hline Germany & 813.31 & 806.26 & 800.23 & - \\
Bulgaria & 723.5 & 726.95 & 745.4 & 756.91 \\
Hungary & 699.41 & 700.15 & 701.9 & 701.29 \\
Romania & 679.12 & 683.99 & 689.21 & 696.83 \\
France & 613.46 & 605.88 & 598.02 & 590.85 \\
Italy & 319.55 & 317.21 & 318.07 & 314.05 \\
Spain & 297.92 & 296.59 & 297.28 & 297.15 \\
European Union - & 512.33 & 508.31 & 504.3 & 500.49 \\
28 (2013-2020) & & & & \\
\hline
\end{tabular}

Source: Authors data processed from Eurostat, 2020

However, as noted in Table 1, since the number of beds per 100.000 inhabitants varies in Europe around the average of 500 beds $/ 100,000$ people, Romania is above the European average, with values close to 700 beds/100,000 people. Also, the two countries that have so far suffered the most in Europe from the COVID-19 pandemic, Italy and Spain, have values around 300 beds $/ 100,000$ people.

It can be stated that the medical infrastructure in Romania has improved in the last years. But the Romanian health system still has many shortcomings: a small number of nurses, relatively outdated and inefficient equipment and insufficient and/or expensive medicines.

\subsection{Hazardous medical waste: legislation, evolution, issues in Romania}

Medical waste is managed within three broad categories: nonhazardous medical waste, hazardous waste and the subcategory of infectious waste. During various medical procedures, the hazardous waste is generated when medical materials have come to interact with blood or some other biological fluids from affected persons. Infectious waste is that medical waste that includes substances and preparations comprising viable microorganisms or their toxins that are known to cause disease in humans or other living organisms; this waste is considered hazardous and covers a good proportion of waste from the treatment of persons that were identified to carry the virus COVID-19.

In the face of a very dangerous epidemic such as the COVID-19 one, the infrastructure needed to dispose of this waste safely is essential. If hazardous infectious medical waste is not properly managed, there is a risk 
of prolonging and returning COVID-19 infections, with all associated negative repercussions. It should be said that proper prevention and management solutions apply to all hazardous medical wastes, not only to infectious wastes from the treatment of COVID-19 patients.

The European Directive 2008/98/EC which regulates waste management activities [7] has been transposed into national law by means of Law 211/2011 on the waste regime [14]. According to Annex No 2 of the law, the disposal of all types of medical waste, dangerous or non-hazardous, must be done either by sterilization (physic-chemical treatment) or by incineration. After sterilisation or cremation, the result of these procedures must be stored in compliant warehouses.

It is important to stress that the medical waste generator is in charge for the safe treatment and elimination of the waste generated. Safe waste disposal can be done both through own disposal facilities or through contracts with specialised operators. Medical facilities are responsible for the selective collection of medical waste, temporary storage (as short term as possible), internal transport under the conditions laid down in the legislation and final disposal - by incineration of hazardous waste or storage of nonhazardous waste, assimilated to household waste.

Since the vast majority of hospital units do not have adequate highperformance incineration plants for hazardous waste, almost $70 \%$ of them have contracted services from specialised firms for the treatment (lowtemperature thermal decontamination) of hazardous waste. [15]

It should be noted that, to date, the GD (Government Decision) comprising the National Strategy on the Management of Waste from Medical Activity was issued on the Ministry of Health's website but has still not been published in the Official Gazette. That means the document has no legal authority.

However, in December 2017 the National Waste Management Plan, which contains a chapter dedicated to medical waste, was approved, outlining the categories of waste considered hazardous and non-hazardous.

Data on medical waste are collected by the National Institute of Public Health (NIPH) from the Territorial Public Health Directorates. The reported quantities represent annual averages, calculated as the arithmetic average of the four quarterly reports until 2010-2012 after which the methodology has changed and, since 2013, the reporting is done by the breakdown of waste according to the codes in the European Waste List [10, $11,12,13]$. 


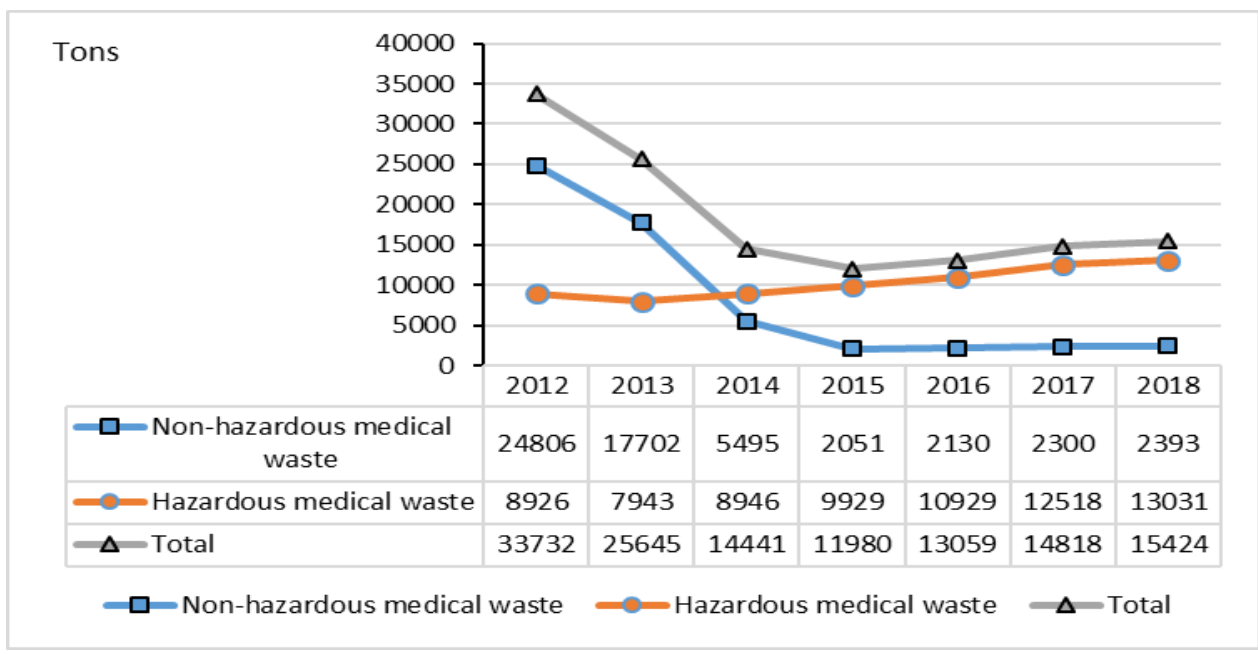

Figure 2. Evolution of medical waste generation

in Romania in sanitary units with beds (tonnes)

Source: Author processing of data from the NPHI [10, 11, 12, 13]

According to the data available, in Romania, generation of medical waste has registered a reduction tendency. From the Figure 2 we notice a significant reduction in the period 2012-2018. The reduction is consistent: more than 18 thousand tons or 54\% from the initial quantity of 33,752 tons. As regarding hazardous medical waste, it has been recorded a steady increase of $45 \%$, in the same period. This development of medical waste is weird and at odds with the fact that the number of hospitals in Romania has increased from 458 in 2008 to 515 in 2018. (Table 1)

Table 2. Generating hazardous medical waste in selected countries

\begin{tabular}{lll}
\hline Country & HMW (kg/bed/day) & Data source \\
\hline USA & 2.79 & UNEP (2012) \\
France & 4.8 & EC (2016) \\
Italy & 2.4 & EC (2016) \\
Turkey & 0.63 & Birpinar et al. (2009) \\
Bulgaria & 0.4 & Spasov (2003) \\
Vietnam & 0.3 & UNEP (2012) \\
Bangladesh & 0.25 & Patwary et al. (2009) \\
Romania & $1-1.8$ & Mihai F.C. (2020) \\
\hline
\end{tabular}

Source: Own selection and research, mainly based on $[3,5,17]$.

As for the average daily quantity of hazardous medical waste per hospital bed, in general, more developed countries (higher GDP/capita) tend to record higher amounts of hazardous medical waste (Table 2). 
Due to the fact that the treatment of all patients requires better protective measures, significant supplementary amounts of hazardous medical waste are going to be generated.

Thus, according to [3], the health waste stream associated with treatment of patients is going to be larger than the usual average and upper limited noticed by earlier reports in Romania. A quantity of (1-1.8 $\mathrm{kg} / \mathrm{bed} /$ day) was taken into account in his analysis. We may assume this formula for estimating the daily quantity of infectious medical waste generated by the Covid-19 active cases in Romania:

Total quantity Covid-19 HMW kg/day = No. of COVID-19 active cases $/$ day $\times(1-$ $1.8 \mathrm{~kg}) / \mathrm{bed} /$ day

Example of applying the formula (in August 2020, there were on average 500 patients in ICU and about 30.000 active cases, as in Figure 1):

Total Covid-19 HMW $/$ day $=30000 \times 1 \mathrm{~kg} / \mathrm{bed} /$ day $+500 \times 1.8 \mathrm{~kg} / \mathrm{bed} /$ day $=30,900$ $\mathrm{kg} /$ day

A potential amount of 30.9 t/day HMW may be generated only due to the Covid-19 pandemic in Romania (August 2020).

\section{Discussions}

\subsection{Analysis and evaluation of the medical waste disposal system}

According to the Health and Environment Report [11, 13], at the level of the health care units, there were 68 medical waste disposal facilities (3 new installations were purchased in 2018), of which 43 equipment/installations are inoperative, due to low economic efficiency, repeated technical failures, high personnel costs, high costs for consumables and maintenance, lack of mechanical processing device, advanced physical and moral wear of equipment, etc. Another important cause is that there are sanitary units that have not obtained environmental authorisation, so waste treatment equipment could not be put into service.

The following treatment/disposal plants for the elimination of medical waste are functioning in Romania: 11 furnaces in a centralised system; 14 cryogenic treatment plants operating in a centralised system; 23 treatment installations in sanitary facilities; five stations for transferring various categories of medical waste. 


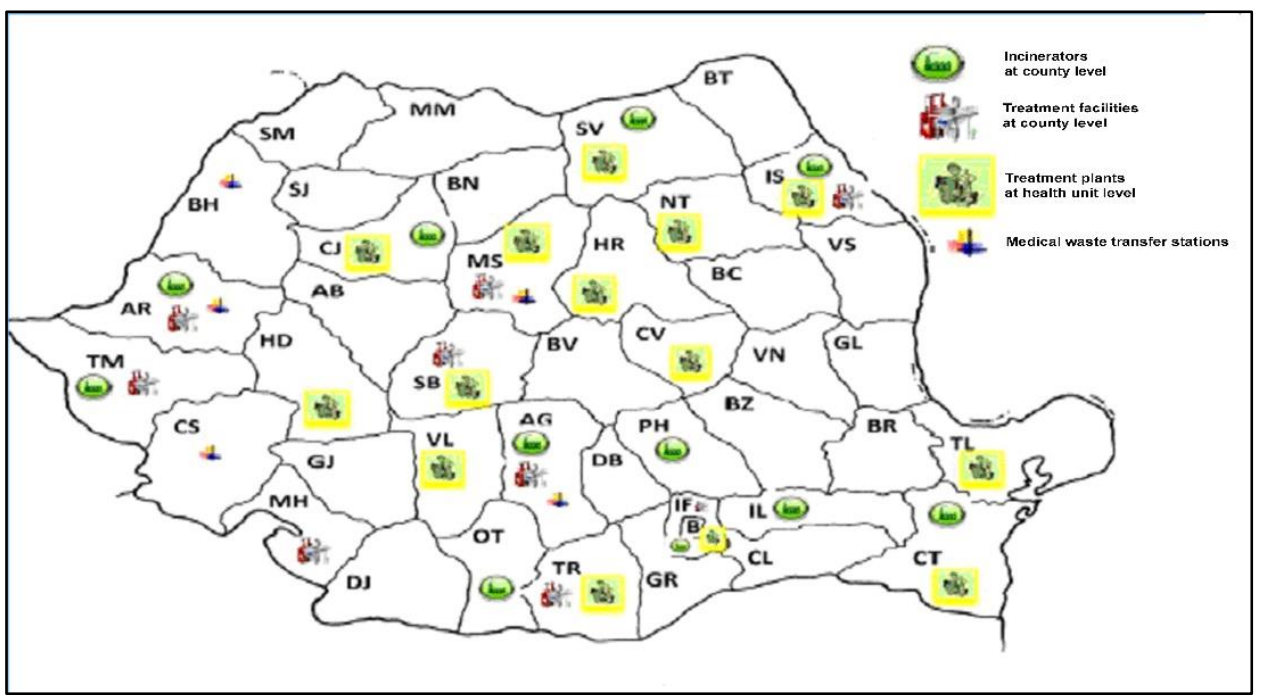

Figure 3. County-level distribution of HMW treatment/disposal capabilities Source: INSP report, 2018 [12].

It can be considered that there are few cryogenic installations for hazardous medical waste. From regional perspective, there is currently no cryogenic installations for hazardous medical waste in 14 counties. As well there is no equipment for hazardous medical waste elimination in 20 counties. The lack of steam autoclaves as decontamination facilities is another problem of the HMW sector in Romania (Figure 3).

Based on the data and reports analysed above, we can estimate that, in Romania, the existing capacity to dispose of hazardous medical waste is approx. 15,000 t/year, out of which: about 11,000 t/year the incineration capacity of HMW; approximately 4,000 t/year the thermal decontamination treatment capacity of HMW at low temperatures.

\subsection{Scenarios for the evolution of the quantities of hazardous medical waste and the investments required for management}

The COVID-19 pandemic has a substantial impact on the generation of infectious medical waste worldwide. For Romania there is no official data available yet but a substantial dynamic of infectious medical waste is expected, requiring extra HWM treatment and disposal facilities (according to our estimates, at about $31 \mathrm{t} \mathrm{HWM/day} \mathrm{generated,} \mathrm{an} \mathrm{additional} \mathrm{capacity}$ of at least $10000 \mathrm{t} /$ year is needed to dispose of Covid-19 infectious waste).

This will increase the costs, but investments are also needed to eliminate the increasing amounts of HMW in Romania. Disposal costs vary greatly in Romania, from 5 lei $/ \mathrm{kg}$ to 50 lei $/ \mathrm{kg}$; some international studies 
report values of 2-8 $€ / \mathrm{kg}$. Specific investments in medical waste disposal facilities differ greatly according to capacity, the technology used, the degree of mechanization/automation, the purification of combustion gases, etc.

The four scenarios we took into account (Table 3) are: Scenario A: $25 \%$ growth of medical waste compared with the quantity generated in 2018; Scenario B: 50\% growth; Scenario C: $75 \%$ growth; Scenario D: $100 \%$ growth in the hazardous medical waste created. The figures also include infectious waste. The starting values of the scenarios are: hazardous waste generated in 2018 ( $t$ /year) - 20,000; existing capacities in 2018 ( $\mathrm{t} /$ year) - 8,000; the Unit Investment Cost $(€ / \mathrm{t})-400$.

Table 3. Four evolution scenarios and the necessary investments

\begin{tabular}{llrrrr}
\hline & & \multicolumn{3}{c}{ Scenarios } \\
\hline Indicators & UM & A & B & C & D \\
\hline Increase from 2018 & $\%$ & 25 & 50 & 75 & 100 \\
HMW generated & Tons/year & 25000 & 30000 & 35000 & 40000 \\
New capacities required & Tons/year & 17000 & 22000 & 27000 & 32000 \\
Spare capacity (15\%) & Tons/year & 2550 & 3300 & 4050 & 4800 \\
Total new capacities & Tons/year & 19550 & 25300 & 31050 & 36800 \\
Cost of investing in equipment & Thou. $€$ & 7820 & 10120 & 12420 & 14720 \\
Cost of special transport equipment & Thou. $€$ & 2737 & 3542 & 4347 & 5152 \\
Other costs (10\% of equipment) & Thou. $€$ & 782 & 1012 & 1242 & 1472 \\
Total costs & Thou. $€$ & $\mathbf{1 1 3 3 9}$ & $\mathbf{1 4 6 7 4}$ & $\mathbf{1 8 0 0 9}$ & $\mathbf{2 1 3 4 4}$ \\
\hline
\end{tabular}

Source: own contribution.

Considering the possible high quantity of infectious HWM to be generated due to the Covid-19 pandemic in Romania, since, according to our estimates, at about $31 \mathrm{t} /$ day, an additional capacity of about $10000 \mathrm{t} /$ year would be needed to dispose of Covid-19 infectious waste, the most likely appear to be the scenarios $\mathrm{B}$ and $\mathrm{C}$ which mean investments with total values between $€ 14.67$ million and $€ 18.00$ million.

It should be said that these calculations are approximations and the actual values depend on many variables that need to be elucidated, such as:

Selected technology and degree of automation;

It is not known exactly which of existing equipment may be granted operating authorisations under the new conditions;

Distances have a great impact on the cost of disposal and it would be desirable to install such equipment in most counties.

\section{Conclusions}

The paper analyses some challenges faced by the sector of hazardous medical waste (HMW) management in Romania, during the COVID-19 pandemic. After the ending of the emergency situation, the resurgence of 
cases in the summer of 2020 was dramatic in Romania, reaching a total of 88000 confirmed cases at the end of August.

To address the growing concern regarding bigger supplementary quantities of hazardous medical waste that will be generated in the context of the pandemic, there are analysed the main current characteristics and issues of the hazardous medical waste management in Romania. One conclusion is that the COVID-19 pandemic only reinforces the challenges for the management of the already growing amounts of hazardous medical waste having occurred in Romania (a rise of 46.5\% in the period 2012-2018).

There have been identified several features and issues in the current HMW management. Romania has fully transposed the EU directives on medical waste. The Health Ministry is in charge for managing this area through the NIPH.

However, with regard to unitary regulation at national level through a strategy, it should be noted that in 2016 the Ministry of Health drafted a proposal for a Government Decision on the National Strategy and the National Plan for the Management of Waste from Medical Activities at National Level. This document has remained at the project stage and has not yet been approved.

Available data on medical waste generated (hazardous and nonhazardous) are difficult to identify and explain. One of the causes is related to the institution presenting the data (Min. Health and/or Min. Environment). National Institute for Public Health (NIPH) reports for 2012-2018 show an extremely complicated development to interpret. Apparently, in 2018 the existing equipment/installations had a combined capacity of approximately 15 thousand tons per year out of which 11000 tons/year of disposal trough incineration and 4000 tons/year of disposal trough cryogenic handling. Unfortunately, there are no data regarding the condition of these facilities: wearing, oldness, remaining live etc. There is too little capacity of thermal decontamination treatment facilities for hazardous medical waste.

Following the analyses carried out and the conclusions, the research team makes the following recommendations:

A. Restoring of a revised Strategy and National Plan regarding the Administration of Medical Waste and official adoption by promulgation as Government Decision. This strategy should determine, either by direct measurements or by sampling, the quantities of hazardous medical waste; the strategy should present a real inventory of existing capacities used in the disposal of medical waste, the degree of wear and capacity use of existing capacities. 
B. Development of a Feasibility Study for new medical waste disposal capabilities; the study should contain a forecast of medical waste that will result in the future from the application of protective measures to COVID-19 infections; recommendations on the most appropriate technology as well as the geographical distribution of new capacities, staggering investments over time.

C. Improving the infrastructure in the sector of hazardous medical waste management, by: ensuring the appropriate conditions for the temporary storage of waste resulting from medical activity in sanitary facilities by the arrangement of refrigeration rooms; ensuring the conditions of internal transport (within the sanitary unit) of waste resulting from medical activity; selection of the best solutions for the handling and final elimination of medical waste.

$D$. Development of a real-time online reporting programme on the generated quantities of medical waste and how to dispose of it; reporting must be mandatory and based on a validated procedure for weighing the medical waste generated (Software and database).

E. Reducing the costs of medical waste management by implementing special measures at different phases of waste management: on-thespot management; comprehensive planning; documentation of hazardous medical waste management costs; personnel measures.

\section{References}

[1] Alverson K. How COVID-19 Pandemic is Changing Waste Management? Health Management. 2020;20(4). Available from: https://healthmanagement $\mathrm{org} / \mathrm{c} /$ healthmanagement/issuearticle/how-covid-19-pandemic-is-changingwaste-management

[2] Calma J. The COVID-19 pandemic is generating tons of medical waste, Sanitation workers need personal protective equipment too. The Verge. 2020 Mar. Available from: https://wwwthevergecom/2020/3/26/21194647/thecovid-19-pandemic-is-generating-tons-of-medical-waste

[3] Mihai FC. Assessment of COVID-19 Waste Flows During the Emergency State in Romania and Related Public Health and Environmental Concerns. Int J Environ Res Public Health. 2020; 17.

[4] Sarkodie SA, Owusu PA. Impact of COVID-19 pandemic on waste management. 2020. Available from: https://doi org/10 1007/s10668-020$\underline{00956-\mathrm{y}}$

[5] Vaccari M, Tudor T, Perteghella A. Costs associated with the management of waste from healthcare facilities: An analysis at national and site level. Waste 
Management \& Research [Internet]. 2018 [cited 2020 Oct 19];36(1):39-47 Available from: https://doi.org/10.1177/0734242X17739968

[6] Sava JA. Number of patients infected with COVID-19 at intensive care in Romania [Internet]. Statista. 2020 Oct 30 [cited 2020 Oct 30]. Available from: https://www.statista.com/statistics/1113942/patients-at-intensivecare-infected-with-covid-19-romania/

[7] Jurnalul Oficial al Uniunii Europene. Directiva 2008/98/CE a Parlamentului European si a Consiliului din 19 noiembrie 2008 privind deseurile si de abrogare a anumitor directive. [Internet] 2008 Nov 22 [cited 2020 Oct 30]. Available from: https://eur-lex.europa.eu/legalcontent/RO/TXT/PDF/?uri=CELEX:32008L0098\&from=RO

[8] European Commission. Shipments of waste in the EU in the context of the Coronavirus crisis [Internet]. 2020 Mar 30 [cited 2020 Oct 20]. Available from:

https://ec.europa.eu/environment/waste/shipments/pdf/waste shipment and COVID19.pdf

[9] European Centre for Disease Prevention and Control: Coronavirus disease 2019 (COVID-19) in the EU/EEA and the UK - 10th update [Internet]. Stockholm. 2020 [cited 2020 Oct 21].

https://www.ecdc.europa.eu/en/publications-data/rapid-risk-assessmentcoronavirus-disease-2019-covid-19-pandemic-tenth-update

[10] Institutul National de Sănătate Publică (INSP). Centrul National de Monitorizare a Riscurilor pentru Mediul Comunitar (CNMRMC). Raportul pentru sănătate si mediu 2015 [Internet]. [cited 2020 Oct 21]. Available from: https://cnmrmc.insp.gov.ro/images/rapoarte/Raport-SM-2015.pdf

[11] Institutul National de Sănătate Publică (INSP). Centrul National de Monitorizare a Riscurilor pentru Mediul Comunitar (CNMRMC). Raportul pentru sănătate si mediu 2016 [Internet]. [cited 2020 Oct 21]. Available from: https://cnmrmc.insp.gov.ro/images/rapoarte/Raport-SM-2016.pdf

[12] Institutul National de Sănătate Publică (INSP). Centrul National de Monitorizare a Riscurilor pentru Mediul Comunitar (CNMRMC). Raportul pentru sănătate si mediu 2017 [Internet]. [cited 2020 Oct 24]. Available from: https://cnmrmc.insp.gov.ro/images/rapoarte/RAPORT\%202017.pdf

[13] Institutul National de Sănătate Publică (INSP). Centrul National de Monitorizare a Riscurilor pentru Mediul Comunitar (CNMRMC). Raportul pentru sănătate si mediu 2018 [Internet]. [cited 2020 Oct 24]. Available from: https://cnmrmc.insp.gov.ro/images/rapoarte/Raport-SM-2018.pdf

[14] Parlamentul Romaniei. Legea 211/2011 privind regimul deseurilor, republicată în Monitorul Oficial, Partea I nr. 220 [Internet]. 28 Mar 2014 
[cited 2020 Oct 21]. Available from:

http://legislatie.just.ro/Public/DetaliiDocument/133184

[15] Ministerul Sănătății. Hotărâre privind Strategia națională si Planul național de gestionare a deseurilor rezultate din activităţi medicale la nivel national [nternet]. [cited 2020 Oct 23]. Available from:

http://old.ms.ro/documente/HG, \%20Anexa\%20nr.\%201\%20si \%202 1229 2508.pdf

[16] UN Environment Programme. Waste management an essential public service in the fight to beat COVID-19 [Internet]. 2020 Mar 24 [cited 2020 Oct 21]. Available from: http://www.unep.org/news-and-stories/pressrelease/waste-management-essential-public-service-fight-beat-covid-19

[17] World Health Organization. Regional guidelines for health care waste management in developing countries (Working document used at the WHO Regional Workshop on Clinical Waste Management, Kuala Lumpur, 28 November - 2 December 1994.) [Internet]. Kuala Lumpur: World Health Organization Western Pacific Regional Environmental Health Centre. 1994 [cited 2020 Oct 20]. Available from:

https://www.who.int/docstore/water sanitation health/wastemanag/ch13. $\underline{\mathrm{htm}}$

[18] World Health Organization. Water, sanitation, hygiene, and waste management for SARS-CoV-2, the virus that causes COVID-19 [Internet]. 2020 Jul 29 [cited 2020 Oct 20]. Available from: https://www.who.int/publications-detail/water-sanitation-hygiene-andwaste-management-for-covid-19

[19] Worldometers - Reported Cases and Deaths by Country, Territory, or Conveyance [nternet]. 2020 September 2 [cited 2020 Oct 20]. Available from:www.worldometers.info/coronavirus/country/romania 